UDC 343.133

DOI https://doi.org/10.32849/2663-5313/2021.11.11

Dmytro Tykhonenkov,

Candidate of Legal Sciences, Associate Professor, Associate Professor at the Department of History of State and Law of Ukraine and Foreign Countries, Yaroslav Mudryi National Law University, 77, Pushkinska street, Kharkiv, Ukraine, postal code 61024, rada001@ukr.net

ORCID: orcid.org/0000-0002-7948-8576

Tykhonenkov, Dmytro (2021). Historical development of the procedural form of the completion of a pre-trial investigation in Ukraine. Entrepreneurship, Economy and Law, 11, 84-89, doi https://doi.org/10.32849/2663-5313/2021.11.11

\title{
HISTORICAL DEVELOPMENT OF THE PROCEDURAL FORM OF THE COMPLETION OF A PRE-TRIAL INVESTIGATION IN UKRAINE
}

Abstract. The purpose of the article is to determine the historical stages of the procedural form of the completion of a pre-trial investigation on the territory of modern Ukraine.

Research methods. The paper is executed by applying the general scientific, historical, comparative, legal and dialectical methods of scientific knowledge.

Results. Historical and legal analysis of the procedural design of the completion of a pre-trial investigation in modern Ukraine has been carried out. The way of formation and historical development of the legal form of the indictment act is presented.

Conclusions. As a result of the study, three main historical stages of formation and development of the procedural design of the end of pre-trial investigation in Ukraine were identified: pre-revolutionary, Soviet and modern. The pre-revolutionary stage covers the time from Kievan Rus to the last years of the Russian Empire. The 1864 judicial reform made most significant changes in the procedural design of the completion of a pre-trial investigation in the pre-revolutionary period. This reform formally defined the duty of the prosecutor to draw up closing indictment in the form of an indictment act. The Soviet stage includes the period from the beginning of the establishment of Soviet government as a result of the civil war of 1917-1922 until the collapse of the USSR in 1991. Initially, the Soviet stage was characterized by the collapse of the achievements of the judicial reform of 1864. However, after the first codification of Soviet law, it was marked by the creation of a legal form of the closing indictment, which lasted with changes for almost a century. There are four most important legal acts of the Soviet stage: 1) Decree of the All-Russian Central Executive Committee "About the Court»" as of March 7, 1918; 2) Criminal Procedure Code of the USSR as of September 13, 1922, which introduced a legal form of closing indictment, consisting of descriptive and operative parts; 3) Criminal Procedure Code of the USSR as of July 20,1927;4) Criminal Procedure Code of Ukraine as of December 28, 1960. The current stage of formation and development of the legal form of the completion of a pre-trial investigation has begun with independence of Ukraine in 1991 and continues to this day. At this stage, the former Soviet legislation was adapted to the new sociopolitical realities, and eventually the new Criminal Procedure Code of Ukraine was adopted on April 13, 2012, which replaced the closing indictment with the indictment act.

Key words: criminal proceedings, criminal procedure legal relations, pre-trial investigation, criminal prosecution, report list, indictment act, closing indictment.

\section{Introduction}

Any concepts and phenomena of objective reality go their own way of formation and development, which occurs in accordance with the basic laws of dialectics as the fundamental logic of the existence and functioning of such concepts and phenomena. A pre-trial investigation and its procedural form, which under the current criminal procedural legislation of Ukraine is expressed in such legal document as an indictment act, are not exceptions. However, long before the appearance of the modern indictment act on the territory of contemporary Ukraine, related forms of the completion of a pre-trial investigation were used, the study of which requires special attention.

The modern form of the indictment act as the final procedural document of the pre-trial investigation stage reflects a long historical path and the accumulated experience of procedural formation of the completion of the pre-trial investigation on the territory of Ukraine. The very concept of modern indictment act is given in part four of Article 110 of the current Criminal 
Procedure Code of Ukraine, being described as a procedural decision in which the prosecutor brings charges of a criminal offense and which ends the pre-trial investigation.

The closest to the current indictment act, both in terms of the time of appearance and its content, is the form of the closing indictment, known since the Soviet period. The latter is almost unanimously understood by experts in the field of criminal procedure as a procedural document containing the accusation formulated in the case, defining the limits of the trial, as well as the system and analysis of evidence and focusing the procedural decision of the competent authorities and officials on the possibility of sending a criminal case to the court to consider it on its merits. At the same time, no direct comparison was made between indictment act and the closing indictment.

In this case, it is noteworthy that if the indictment act is legally defined through the category of "procedural decision", then in relation to the closing indictment, the term "procedural document" is used. This difference indicates a shift in emphasis in the context of the form and content of the procedural form of the completion of a pre-trial investigation: if the Soviet legislator adhered to the classical logic of transition from the external form to the internal content, then in the current criminal procedural legislation of Ukraine there is a regulation from content to form, where the latter occupies dominant place. Undoubtedly, this leaves its imprint on the peculiarities of law enforcement both at the stage of pre-trial investigation and during judicial consideration of criminal cases. Thus, the relevance of the study is supported by the need for a better understanding of the nature and essence of the modern indictment act by all participants of the criminal process.

Many scientists, in particular Ya.A. Grishin, T.A. Gumerov, N.A. Yakubovich and others, have devoted their works to the study of the historical and modern forms of the completion of a pre-trial investigation. At the same time, a comprehensive study with the identification of the historical stages of the procedural form of the completion of the pre-trial investigation was not carried out. With this in mind, the purpose of this article is to conduct an analysis using general scientific, historical, comparative, legal and dialectical methods of scientific knowledge for determination of the historical stages of the procedural form of the completion of the pre-trial investigation on the territory of modern Ukraine, while the specific tasks of the research include the periodization of the main historical stages in the development of the legal form of the final document of the pre-trial investigation, the identification of the features of each such stage and the overview of historical roots of the modern indictment act.

2. Criterion for identifying individual stages in the development of the indictment concept

The section reveals the key features of the legal form of the indictment as the main criterion for identifying the historical stages of the indictment's development on the territory of modern Ukraine.

Even long before the appearance of the terms "indictment act" and "closing indictment" and their legal consolidation in codified acts of criminal procedure legislation of Ukraine, positive law and its subsequent enforcement faced the gradual formation of certain substantive key signs that symbolized the end of the stage of the pre-trial investigation. T.A. Gumerov justly notes: "Like any other legal institution, the indictment and the problems of its drafting are rooted in the depths of centuries, transforming and changing depending on the characteristics of a particular state, its legal structure, form of government and political regime" (Gumerov, 2011, p. 4).

It is also important that as a result ofthehistoricalandlegalanalysisoftheprocedural formation of the completion of the pre-trial investigation, it becomes possible not only to consider the final individual procedural documents and decisions of the investigation, but also to highlight the corresponding historical stages of their existence. Such stages on the territory of modern Ukraine can be considered: 1) the pre-revolutionary stage, covering the time from Kievan Rus to the last years of the existence of the Russian Empire; 2) the Soviet stage, including the period from the beginning of the establishment of Soviet power as a result of the civil war of 1917-1922 and until the collapse of the USSR in 1991; 3 ) the modern stage, which started at the moment when Ukraine gained independence in 1991 and continues to this day. Each of these stages is characterized by its own individual features of legal regulation of the end of the pre-trial investigation and the approach to determining the form and content of the main effective legal document that specifies the essence of the official charge and the boundaries of the subsequent trial.

3. The pre-revolutionary stage of the development of a procedural form of the completion of a pre-trial investigation $\left(\mathbf{1 0}^{\text {th }}-\mathbf{2 0}^{\text {th }}\right.$ centuries $)$

The section reveals the features of the first stage in formation of the legal form of the indictment on the territory of modern Ukraine, covering the period from the $10^{\text {th }}$ to the $20^{\text {th }}$ centuries. 
The pre-revolutionary stage is the longest, and the establishment of the institutions of the court and pre-trial investigation goes back to the time of the formation of statehood on the territory of modern Ukraine. In particular, based on the content of the Russian-Byzantine agreement of 911 , it can be concluded that society already then renounced arbitrariness and demanded an official trial of criminals. At the same time, due to the lack of parchment and the poor development of written office work in Kievan Rus, there were no documentary forms of pre-trial investigation (Gumerov, 2011 , p. 8). At the beginning of the $11^{\text {th }}$ century, Russkaya Pravda consolidated the first ancient procedural forms of a pre-trial investigation in the form of persecution of the trace and vault (Tikhomirov, 1953, pp. 87-112).

The time of feudal fragmentation in Russia was characterized by the accumulation of a variety of procedural forms of pre-trial activities, and the appearance of such documents as the oath (for parties, the governor of the prince, witnesses), summons, letter of delivery of the defendant, bill of indictment. Their legal regulation was carried out on the basis of veche legislation, in particular, the Pskov Judicial Charter of 1397. The development of these procedural forms continued in the Code of Laws of Ivan III of 1497 - a normative legal act, which was a set of laws of the Russian state, created with the aim of systematizing the norms of law existing at that time. Its article 16 enshrined such a legal form as a report list, which, at the same time, acted as an indictment and a protocol of the court session, in which the court, which is also the investigative body, brought charges against the suspect and made a decision itself. The decision was not recorded in the report list, but was formalized by a legal letter, which was drawn up by a special official - a deacon or clerk (Gumerov, 2011, pp. 11-12). In turn, Articles 4 and 5 of the Code of Law of Ivan IV of 1550 additionally introduced criminal prosecution of an official for incorrect presentation (distortion) of the report list. Thus, the increased requirements of the society to the procedural registration of the pre-trial investigation were consolidated and the prerequisites were created for the formation of a form of indictment with the further improvement of legislation.

The appearance of a procedural document as close as possible to the indictment is evidenced by Article 4 of the Decree of Peter I "On the Form of the Court" of November 5, 1723. In accordance with the norm enshrined in it, "before the trial (except for these cases: treason, villainy, or words contrary to the Imperial Majesty and His Majesty's surname and revolt), it is necessary to give a list to the defendant with the items submitted from the petitioners, in order to lead to acquittal, thus, calling the defendant before the court, and to give the list to him; on which to mark all judging the number in which to stand before the court" (Gumerov, 2011, p. 17).

Themostsignificantchangesintheprocedural formation of the completion of the pre-trial investigation in the pre-revolutionary time were brought by the Judicial Reform of 1864 . This reform, in addition to the introduction of a clear system of courts, the same for all parts of the Russian Empire, the adoption of new judicial charters that enshrined the democratic principles of legal proceedings, the introduction of the institutions of justices of the peace, attorneys at law (advocacy) and the jury, officially determined the duty of the prosecutor to draw up the closing indictment in the form of the indictment act. This was directly enshrined in Article 519 of the Charter of Criminal Proceedings of November 20, 1864, in accordance to which the indictment must include the following data: 1) an event containing signs of a criminal act; 2) the time and place of the commission of this criminal act, as far as is known; 3) the title, name, patronymic and surname or nickname of the accused; 4) the nature of the evidence collected in the case against the accused; 5) definition according to the law: to which particular crime the signs of the act in question correspond. According to article 521 of the Charter, the prosecutor attaches to the indictment act a list of persons who, in his opinion, should be summoned to the judicial investigation. In 1864, immediately after the adoption of the Charter of criminal proceedings, P.I. Lyublinskiy noted: "This Charter must be considered as a law addressed to citizens, about the rights that are given to them to protect from the arbitrariness of the state and judicial authorities, and not only as a set of prescriptions for judicial authorities on the forms of legal process" (Lyublinskiy, 1906, p. 11). This important achievement actually ended the pre-revolutionary stage in the development of the procedural form of the end of the pre-trial investigation.

4. The Soviet stage of the development of a procedural form of the completion of a pre-trial investigation (1918-1991)

The section reveals the features of the second stage in formation of the legal form of the indictment on the territory of modern Ukraine, covering the period from the beginning of formation till the collapse of the Soviet Union.

The next, Soviet stage began in the difficult times of the Civil War and at first took place against the background of the collapse 
of the achievements of the Judicial Reform of 1864, however, after the first codification of Soviet legislation, it was marked by the creation of a legal form of the closing indictment, which existed with appropriate changes for almost century.

Four most important normative legal acts of this stage should be highlighted: 1) Decree of the All-Russian Central Executive Committee "On the Court" dated March 7, 1918 № 2, in accordance with Article 22 of "which in criminal cases, the indictment act is replaced by a resolution of the investigative commission on trial. If such by a district people's court was found to be insufficiently substantiated, then it depends on it to return the case to the commission of inquiry for further investigation or to entrust it to one of the members of the court" (AllRussian Central Executive Committee, 1918); 2) the Criminal Procedure Code of the Ukrainian SSR of September 13, 1922, which introduced the legal form of the closing indictment, consisting of descriptive and operative parts (All-Ukrainian Central Executive Committee, 1922); 3) the Criminal Procedure Code of the Ukrainian SSR of July 20, 1927, the articles of which in a new way regulated the activities of the preliminary investigation bodies, the prosecutor's office and the court, in particular, expanded the rights of investigators and prosecutors to close criminal cases in the absence of corpus delicti; 4) Criminal Procedure Code of Ukraine of December 28, 1960 № 1001-05, which, with amendments, continued to operate for the first twenty years after the collapse of the Soviet Union (Verkhovna Rada of the Ukrainian SSR, 1961).

5 . The modern stage of the development of a procedural form of the completion of a pretrial investigation (since 1991 - to this day)

The section reveals the key features and achievements of the third stage in formation of the legal form of the indictment, covering the period from the adoption of independence by the Ukrainian parliament on August 24, 1991 to the present day.

The modern stage in the development of the procedural form of the completion of the pre-trial investigation began when Ukraine gained its independence - in 1991. At first, this stage was characterized by the adaptation of the former Soviet legislation to the new socio-political realities, the approval of Ukraine as a full-fledged member of the international community, including the signing and ratification of the European Convention on Human Rights and its protocols with the subsequent implementation of the convention into the national legal order of Ukraine.

The key event of the current stage became the adoption of the Criminal Procedure Code of April 13, 2012 № 4651-VI, which, among other things, replaced the legal form of the closing indictment with the legal form of the indictment act with the rejection of the structural division into descriptive and operative parts, but with a clear regulation of the list of data that is subject to mandatory inclusion in the indictment act (Verkhovna Rada of Ukraine, 2013).

\section{Conclusions}

As a result of the study, three main historical stages of formation and development of the procedural design of the end of pre-trial investigation in Ukraine were identified: prerevolutionary, Soviet and modern. The prerevolutionary stage covers the time from Kievan Rus to the last years of the Russian Empire. The most significant changes in the procedural design of the completion of pre-trial investigation in the pre-revolutionary period were brought by the judicial reform of 1864 . This reform formally defined the duty of the prosecutor to draw up closing indictment in the form of an indictment act. The Soviet stage includes the period from the beginning of the establishment of soviet government as a result of the civil war of 1917-1922 until the collapse of the USSR in 1991. Initially, the Soviet stage was characterized by the collapse of the achievements of the judicial reform of 1864, but after the first codification of soviet law was marked by the creation of a legal form of the closing indictment, which lasted with changes for almost a century. There are four most important legal acts of the soviet stage: 1) Decree of the All-Russian Central Executive Committee "About the Court" of March 7, 1918; 2) Criminal Procedure Code of the USSR of September 13, 1922, which introduced a legal form of closing indictment, consisting of descriptive and operative parts; 3) Criminal Procedure Code of the USSR of July 20, 1927; 4) Criminal Procedure Code of Ukraine of December 28, 1960. The current stage of formation and development of the legal form of the completion of a pre-trial investigation has begun with independence of Ukraine in 1991 and continues to this day. At this stage, the former Soviet legislation was adapted to the new socio-political realities, and eventually, the new Criminal Procedure Code of Ukraine, which replaced the closing indictment with the indictment act, was adopted on April 13, 2012. 


\section{References:}

Alekseev, Yu.G. (2001). Sudebnik Ivana III: tradiciya i reforma [The Code of Law of Ivan III: tradition and reform]. Saint Petersburg: Dmitrij Bulanin, 448 p. (in Russian).

All-Russian Central Executive Committee (1918). O sude: Dekret Vserossiyskogo tsentral'nogo ispolnitel'nogo komiteta ot 7 marta 1918 g. № 2 [On the Court: Decree of the All-Russian Central Executive Committee of March 7, 1918 № 2]. Sobranie uzakonenij i rasporyazhenij rabochego $i$ krest'yanskogo Pravitel'stva RSFSR, no. 26 (in Russian).

All-Ukrainian Central Executive Committee (1922). Ugolovno-protsessual'nyy kodeks USSR ot 13 sentyabrya $1922 \mathrm{~g}$. [Criminal Procedure Code of the Ukrainian SSR of September 13, 1922]. Moscow: NKYu, 469 p. (in Russian).

Belyaev, I.D. (1888). Lekcii po istorii russkogo zakonodatel'stva [Lectures on the history of Russian legislation]. Moscow: Tipografiya A.A. Karceva, 584 p. (in Russian).

Cherepnin, L.V. (transl.) (1940). Pskovskaya sudnaya gramota [Pskov Judicial Charter]. Retrieved from: https://elf.ucoz.net/Pravo/IOGP/pskov sud gram.pdf (in Russian).

Chistyakov, O.I. (ed.) (1991). Rossiyskoe zakonodatel'stvo X-XX vekov [Russian legislation of the $X-X X$ centuries], in 9 vols. Moscow: Yuridicheskaya literature, vol. 8, 496 p. (in Russian).

Gumerov, T.A. (2011). Obvinitel'noe zaklyuchenie: pravovaya priroda, soderzhanie, procesual'nye posledstviya: monografiya [The indictment: legal nature, content, procedural consequences: monograph]. Moscow: Yurlitinform, 216 p. (in Russian).

Lyublinskiy, P.I. (1906). Svoboda lichnosti v ugolovnom processe [Personal freedom in criminal proceedings]. Saint Petersburg: Senatskaya tipografiya, 701 p. (in Russian).

Muratova, N.G. (1989). Processual'nye akty organov predvaritel'nogo rassledovaniya. Voprosy teorii i praktiki: monografiya [Procedural acts of the bodies of preliminary investigation. Questions of theory and practice: monograph]. Kazan: Izd-vo Kazanskogo un-ta, 118 p. (in Russian).

Pitercev, S.K. (1982). Sostavlenie obvinitel'nogo zaklyucheniya: uchebnoe posobie [Drawing up an indictment: textbook]. Leningrad: In-t usoversh. sledstv. rabotnikov, 63 p. (in Russian).

Shargey, M.E. (1928). Ugolovno-protsessual'nyy kodeks USSR 1927 goda: tekst i postateynyy prakticheskiy kommentariy [Code of Criminal Procedure of the Ukrainian SSR of 1927: text and article-by-article practical commentary]. Kharkiv: Yuridicheskoe izdatel'stvo NKYU USSR, 356 p. (in Russian)

Tikhomirov, M.N. (1953). Posobie po izucheniyu Russkoj Pravdy [A guide to the study of Rus' Truth]. Moscow: Izd-vo Moskovskogo un-ta, 192 p. (in Russian).

Verkhovna Rada of the Ukrainian SSR (1961). Kryminalno-protsesualnyi kodeks Ukrainy: Zakon Ukrainy vid 28 hrudnia 1960 r. № 1001-05 [Code of Criminal Procedure of Ukraine: Law of Ukraine of December 28, 1960 № 1001-05]. Vidomosti Verkhornoi Rady URSR, no. 2, art. 15 (in Ukrainian).

Verkhovna Rada of Ukraine (2013). Kryminalnyi protsesualnyi kodeks Ukrainy: Zakon Ukrainy vid 13 kvitnia 2012 r. № 4651-VI [Criminal Procedure Code of Ukraine: Law of Ukraine of April 13, 2012 № 4651-VI]. Vidomosti Verkhoonoi Rady Ukrainy, no. 9-10, pp. 474 (in Ukrainian).

Yakubovich, N.A. (1962). Okonchanie predvaritel'nogo sledstviya [The end of the preliminary investigation]. Moscow: Gosyurizdat, 147 p. (in Russian).

\section{Дмитро Тихоненков,}

кандидат юридичних наук, доцент, доцент кафедри історії держави та права Украӥни та зарубіжних країн, Національний юридичний університет імені Ярослава Мудрого, вулиия Пушкінська, 77, Харків, Україна, індекс 61024, rada001@ukr.net

ORCID: orcid.org/0000-0002-7948-8576

\section{ІСТОРИЧНИЙ РОЗВИТОК ПРОЦЕСУАЛЬНОЇ ФОРМИ ЗАКІНЧЕННЯ ДОСУДОВОГО СЛІДСТВА В УКРАЇНІ}

Анотація. Метою статmi є визначення історичних етапів процесуальної форми закінчення досудового розслідування на теренах сучасної України.

Методи дослідження. Статтю виконано із застосуванням загальнонаукових та спеціальних методів наукового пізнання.

Результати. Проведено історико-правовий аналіз процесуального оформлення закінчення досудового слідства на території сучасної України. Представлено шлях формування та історичний розвиток правової форми обвинувального акта.

Висновки. Унаслідок проведеного дослідження визначено три основні історичні етапи становлення й розвитку процесуального оформлення закінчення досудового слідства в Україні: 
дореволюційний, радянський та сучасний. Дореволюційний етап охоплює час від Київської Русі до останніх років існування Російської імперії. Найбільш значущі зміни у процесуальне оформлення закінчення досудового слідства в дореволюційний період привнесла судова реформа 1864 р., якою було офіційно визначено обов’язок прокурора скласти обвинувальний висновок у формі обвинувального акта. Радянський етап включає період із початку встановлення радянської влади як результату громадянської війни 1917-1922 рр. до розпаду СРСР у 1991 р. Спочатку радянський етап проходив на тлі згортання досягнень судової реформи 1864 р., однак після першої кодифікації радянського законодавства ознаменувався створенням правової форми обвинувального висновку, що проіснувала з відповідними змінами майже століття. Названо чотири найбільш важливі нормативно-правові акти радянського етапу: 1) Декрет Всеросійського центрального виконавчого комітету «Про суд» від 7 березня 1918 р.; 2) Кримінально-процесуальний кодекс УСРР від 13 вересня 1922 р., який запровадив правову форму обвинувального висновку, що складалася 3 описової та резолютивної частин; 3) Кримінально-процесуальний кодекс УСРР від 20 липня 1927 р.; 4) Кримінально-процесуальний кодекс України від 28 грудня 1960 р. Сучасний етап становлення й розвитку правової форми закінчення досудового слідства розпочався з моменту здобуття Україною незалежності в 1991 р. та триває донині. На цьому етапі відбулася адаптація колишнього радянського законодавства до нових суспільно-політичних реалій, а також був прийнятий Кримінальний процесуальний кодекс України від 13 квітня 2012 р., який змінив правову форму обвинувального висновку на правову форму обвинувального акта.

Ключові слова: кримінальне провадження, кримінально-процесуальні правовідносини, досудове слідство, кримінальне обвинувачення, доповідний список, обвинувальний акт, обвинувальний висновок.

The article was submitted 15.11.2021 The article was revised 06.12.2021 The article was accepted 27.12.2021 